\title{
Evaluating the Readiness of Malaysian Academic University Libraries Towards Library 4.0
}

\author{
https://doi.org/10.3991/ijim.v14i06.13477 \\ Sabri Mohamad Sharif $(\bowtie)$ \\ Universiti Teknikal Malaysia Melaka (UTeM), Melaka, Malaysia \\ sabri@utem.edu.my \\ Ahmad Zam Hariro Samsudin, Anum Shafeera Amdan \\ Universiti Teknologi MARA (UiTM), Selangor, Malaysia
}

\begin{abstract}
This paper evaluates the readiness of Malaysian academic university libraries towards Library 4.0. The rise of this new intervention of Web 4.0 and Library 4.0 are being deliberated among librarians for future services. Information technology facilities have been identified and analysed which may comprehend the use of libraries for the next generation. This will also help to move the library forward and improve the overall performance of university libraries respectively. The methodology used for this study is qualitative. This qualitative study was piloted among librarians working in the selected academic university libraries. This study gives an outline of the readiness among the selected academic university libraries towards Library 4.0
\end{abstract}

Keywords-Library 4.0 Academic Libraries

\section{Introduction}

Over the past ten years, Library and Information Science (LIS) has been discussed on Library 3.0. Due to the advancement of the new technology all around the world, librarians and researchers are among those who have been impacted generally. The changes that take effect are in a large amount while the time for any implementation to take place is very short. Thus, they must think of the resolution in developing the libraries according to the new requirement needed. Libraries are the same as those living creatures. They change is based on the development of the technological environment and depends on the use of web services specifically. Since the pressure from the outside sources is perennial, libraries will have to evolve as well. Rohrbeck et al. [1] stated that human being and technology will unite and at the same time, it passed by very quickly.

In Web 1.0, television is an example of passive entertainment. Blogs and podcast are other examples of Web 2.0 which signify the content stage [2]. As for Web 3.0, people are most likely to go into the virtual medium like social media. Web 4.0, where the future will be is when users are connected via online using the technological devices [3]. According to Kirschner and Muller [2], especially the young people; 
they are already connected to one another as in talking to their close ones. There is not much of a difference as compared to previous generation.

Callari [4] mentioned that in Web 3.0, Artificial Intelligence screens the data received and then analyses it. Meanwhile, for Web 4.0, people and the new technology will merge. The three conditions set by Godin [5] in Web 4.0 are ubiquity, identity and the connection. For Web 4.0, ubiquity can be defined as the line either in offline or in an online based anywhere and anytime possible. For identity, the set protocols will know the users, what they do and things they require at that time. Lastly, the connection is network of users. Again, assumed by Godin [5] when Web 4.0 takes in place, all that irrelevant information will be removed unlike the past where users received a lot of information when they do the searching of information on their own. For instance, any customers that passed by a store, will be recognized and later an ad will be sent personally to them. The existence of those web will influence the changing of Library 4.0 in this context and display new criteria which carry the uniqueness of the libraries. Library 3.0 has interrelated concepts of social semantic library, linked library and mobile library [6]. Thus, it is recommended for us to start discussing on criteria for Library 4.0 for the implementation in the libraries. The discussion has slowly been introduced and recognized by the librarians to embrace the new concept so that they remain relevant in the field. As a matter of fact, libraries should start to predict the future direction by now so that librarians can demonstrate their role in leading towards Library 4.0. Even though the discussion for Web 4.0 has been made, it is hard to allocate study that determines the actual criteria of Web 4.0. The researchers are progressively introducing the elements needed for the transformation towards Library 4.0. It is very important to kick off as well as to focus on the right way and its approaches.

Along with the achievement, the librarians will help to expand concepts for Web 4.0. Today, most of us can easily connect to any devices in order to get the access. Unlike many years ago where not many people can get the same benefit for whatever they have right now. Technology keeps changing and the new trends continues coming in drastically. It is growing fast and keeps changing how we live, work and communicate to one and another. It is important for librarians to stay abreast in the current market due to these fast-moving trends. Digital and Smart Library are part of the global changes for Library 4.0. The technology itself is using a remote control to take care of the library. With all the services and facilities equipped, the opening hours of the library can be extended, and more users can come and use the library at their convenient time. This paper describes the criteria of Library 4.0 and evaluates the readiness among selected university libraries. The respondents were the librarians while data were collected using the qualitative method. The technology drives peoples to access the gadget almost in every facet. Due to the changing demand, the library is progressively actively. As such, this study tends to propose a framework model of criteria for Library 4.0 by evaluating the readiness in university libraries. The framework model is developed to fit every university library in Malaysia. 


\section{$2 \quad$ Literature Review}

The thought of having a direction for future libraries through the new development has already been discussed. With the rapid changes due to the advancement of the technology on new concepts and how huge the influences into human being, the researcher began to think on the duration the libraries will stay and how it will be created at that time. This paper evaluates the readiness of Malaysia selected academic universities libraries towards Library 4.0. Since the available resources on Library 4.0 are few, the focus is made to follow the criteria of Web 4.0 and next to apply for current libraries. The previous studies mentioned on identifying and analyzing the criteria of digital libraries starting from the first generation towards present libraries. The suggestion is for future generation to use the services in the libraries. Greenstein and Thorin [7] shared their experiences from the research libraries in USA and also the risk in developing the future libraries considering its cultural, legal and monetary support which will take effect on the history process and the direction to move forward in the long run.

On the other hand, Mukaiyama [8] argued that in the 21st century and with the influences from the technology, digital libraries will be developed for the next generation. According to Mukaiyama [8], there are three technologies applied in libraries such as architecture system, individual and integration. The criteria of current digital libraries as described by Kroski [9] are the mobile libraries, social and open. In general, all technologies listed match the direction for Web 4.0 elements. In contrast, Breeding [10] claimed the plan is indispensable for creating the future libraries so as to make use of the technologies soonest possible and to evade from being superseded. Until now, he added that the differences are the format for the libraries. Even though the present RFID system operates automatically, simple for the physical material can reduce its worth. Nevertheless, he cannot decide which technology is significant for the future libraries. Piper [11] mentioned a model that gives the guidelines in creating a massive library will be created within 15 years from now. It involves to include searching online, books to be written in all languages and scope and lastly, to assist user in searching the books using user-based system. The history on previous support between organization till now is impossible to be realized. McGettigan [12] established some initiatives, such as information services, virtual reference services, media and one whole service hour. Ideas generated are based on services rendered to community like free network and free technology resources with local people.

As stated by Sackey et al., [13] and Sharif et al., [14], this support facilitating the library system with its key role in helping to develop the creative content, collaborate resources, communicate machine to machine and machine to men. Globally, there are huge opportunities for the libraries to step forward based on the current demand from the users. It is an important role towards the technologies that are involved in their development and implementation [13]. Technology advancements will bring reduction in time, cost optimization, machine visualization and operations, design of experiments, layout markings and value addition in supply chain logistics, ergonomic analysis and man-machine interactions, and in robotics systems optimization [15] [26], [27], [36]-[45], [28], [46]-[48], [29]-[35]. Library 4.0 should work and recognize 
those potentials in transforming the libraries with the latest knowledge and insights for becoming part of the transformation. The stress is on the future technology, such as in information, communication and automation, robotics and artificial intelligence (AI), is crucial so as to meet user expectations, before becoming obsolete.

\subsection{Cloud Computing}

Cloud computing is the use of internet for computing needs. It is freely accessible. It is used to establish and circulate the information to users [16].

\section{$2.2 \quad$ Geotagging}

Geotagging provides the location, coordinate and distance of library materials to users. It offers the users to locate the information that they require.

\subsection{Artificial Intelligence (AI)}

It is creating machine that can engage on human behaviours that human considers intelligent. AI involves expert system, fuzzy logic, artificial neural network, evolutionary algorithms, case base reasoning, image processing, natural language processing, speech recognition and robotic.

Chauhan [17] claimed that one day library will become intelligent library. It can analyse the information on its own and decide the solutions with the users around.

\subsection{Big Data}

Big data store and analyse large or compound information [18]. The future libraries carry massive data and services.

Big data is a large data set which is impossible to collect, store, manage, or even analysed by ordinary database due to its limitation [19].

Good thing about big data is that it saves the cost while improving the decision making [20].

\subsection{Augmented Reality (AR)}

Augmented Reality is installed in mobile which users can practise into the actual world [21]. Dunston [22] expressed new technology can be in 3D where unlimited data share, use anytime they want. This new technology is categorized for the purpose of finding a location. Users will be looking at the directions created by others using image recognition [23]. The system should be able to trace the information and the location of the books using the catalogue and guidance from the technology proposed. It is more convenient and needful to users in finding the right materials they want. 


\subsection{Cutting-Edge Displays}

These are successful implementations of technological advancements and their use in library environments particularly those that libraries develop themselves. Library displays a wonderful collection of art.

\subsection{Infinite Creative Spaces}

The collaboration between infinite creative spaces and library services is a revolution that will attract users to come. It allows the users to view the libraries in a different perspective and create the chance to venture and think of a way to move ahead. The idea is to build a space using the technology. Creative people with creative space can leads to creative innovation and solutions. The intention is to get the users together to create something with the technology provided in the libraries. As expressed by Camoprodon et al.[24], important things to consider for infinite creative spaces are coworking, makerspaces and community. Similarly, Noh [25] added 12 concepts for the infinite creative space. It will be used by many users for any programs and activities.

\subsection{Open Source}

The term "open source" refers to something people can modify and share because its design is publicly accessible. A software development is to designate a specific approach to creating computer programs. Open source systems for libraries have improved significantly to gain the confidence of librarians

\section{$3 \quad$ Research Methodology}

Methodology is one of the rationale methods used and not from philosophical assumptions in a research. The method used in this study is qualitative. This is due to qualitative methodology helps to collect in-depth data from the respondents through face-to-face interviews questions and open-ended questionnaires. Purposive sampling was used in selecting five academic university libraries

\section{$4 \quad$ Findings}

\subsection{Library 4.0 compliance}

Table 1 shows the results regarding the compliance of the five selected academic university libraries towards Library 4.0 elements. 
Table 1. Compliance of the five selected academic university libraries towards Library 4.0

\begin{tabular}{|c|l|c|c|c|c|c|}
\hline No. & Library 4.0 elements & $\begin{array}{c}\text { Academic } \\
\text { Library 1 }\end{array}$ & $\begin{array}{c}\text { Academic } \\
\text { Library 2 }\end{array}$ & $\begin{array}{c}\text { Academic } \\
\text { Library 3 }\end{array}$ & $\begin{array}{c}\text { Academic } \\
\text { Library 4 }\end{array}$ & $\begin{array}{c}\text { Academic } \\
\text { Library 5 }\end{array}$ \\
\hline 1 & Cloud Computing & $\sqrt{ }$ & $\sqrt{ }$ & $\sqrt{ }$ & $\sqrt{ }$ & $\sqrt{ }$ \\
\hline 2 & Geotagging & & & & & \\
\hline 3 & Artificial Intelligence & & & & & \\
\hline 4 & Big Data & $\sqrt{ }$ & $\sqrt{ }$ & $\sqrt{ }$ & $\sqrt{ }$ & $\sqrt{ }$ \\
\hline 5 & Augmented Reality (AR) & & & & & \\
\hline 6 & Cutting-Edge Displays & $\sqrt{ }$ & $\sqrt{ }$ & $\sqrt{ }$ & $\sqrt{ }$ & $\sqrt{ }$ \\
\hline 7 & Infinite Creative Spaces & $\sqrt{ }$ & $\sqrt{ }$ & $\sqrt{ }$ & $\sqrt{ }$ & $\sqrt{ }$ \\
\hline 8 & Open Source & $\sqrt{ }$ & $\sqrt{ }$ & $\sqrt{ }$ & $\sqrt{ }$ \\
\hline
\end{tabular}

\section{$5 \quad$ Discussion and Conclusion}

The findings of this study show the five selected academic universities libraries are in the midst of fulfilling the criteria for Library 4.0. Among the practices are Cloud computing, Big Data, Cutting-Edge Displays, Infinite Creative Spaces and Open Source. This study can be useful to motivate other academic university libraries towards Library 4.0 practices. It is clear from this study that the initiatives must be clearly communicated in the organization so that all librarians are aware on its importance and usefulness. It is hoped that this paper gives an understanding about the issue which can help to bridge the gap.

\section{Acknowledgement}

The authors would like to express gratitude to Universiti Teknologi MARA (UiTM) for supporting this research.

\section{$7 \quad$ References}

[1] R. Rohrbeck, C. Battistella, and E. Huizingh, "The road ahead for research on Corporate foresight.," Rep. Corp. foresight track ISPIM Annu. Conf., 2012.

[2] R. K. Kirschner and H. R. Muller, "U.S. Patent no. 4,467,967.," Washington, DC U.S. Pat. Trademark Off., 1987.

[3] D. Farber, “"From semantic Web (3.0) to the WebOS (4.0)'.," Int. J. Web Semant. Technol., vol. 3, no. 1, 2007.

[4] R. Callari, “'Web 4.0, Trip Down the Rabbit Hole Brave New World?,” 2009.

[5] S. Godin, “"Web4,"” 2007.

[6] Y. Noh, "A study on Library 3.0 concept and its service model.," J. Korean Soc. Inf. Manag., vol. 27, no. 4, pp. 283-307, 2010.

[7] S. E. Greenstein, D., \& Thorin, "The Digital Library: A biography.," Digit. Libr. Fed. Counc. Libr. Inf. Resour., pp. 1-70, 2002.

[8] H. Mukaiyama, "Technical aspect of next generation digital library project. ISRDP in digital libraries.," 1997.

[9] E. Kroski, "On the move with mobile web: Libraries and mobile technologies.," 2009. 
[10] M. Breeding, "The system librarian. Preparing for the long-term digital future of libraries.," Comput. Libr., vol. 31, no. 1, pp. 24-26, 2011.

[11] P. S. Piper, "HathiTrust and Digital Public Library of America as the future.," Online Search., pp. 22-26, 2013.

[12] L. McGettigan, "Unafraid of the future-Edinburgh's next generation library and information services.," IFLA., 2013.

[13] S. M. Sackey, A. Bester, and D. Adams, "Industry 4.0 learning factory didactic design parameters for industrial engineering education in South Africa.," South African J. Ind. Eng., vol. 28, no. 1, 2017. https://doi.org/10.7166/28-1-1584

[14] S. M. Sharif, N. Z. Nizam, N. A. Rashid, N. R. Masrom, and M. H. Bakri., "Role of values and competencies in university intellectual property commercialization: A critical review.," Turkish Online J. Des. Art Commun. - TOJDAC, pp. 887-904, 2018. https://doi. org/10.7456/1080sse/125

[15] D. Plinta, "New information technologies in production enterprises, Advanced-industrial engineering, Industry 4.0.," Bielsko-Biała, pp. 7-20, 2016.

[16] J. Cho, "A study on the cloud collection.," J. Korean Libr. Inf. Sci. Soc., vol. 43, no. 1, pp. 201-219, 2012.

[17] S. K. Chauhan, "Library4.0.," 2009.

[18] D. Burrus, "Bigthink: FromWeb 3.0 to Web 4.0," 2013.

[19] J. Manyika et al., "Big Data: The Next Frontier for Innovation, Competition, and Productivity.," Mckinsey Glob. Institute., 2011.

[20] D. Lehong, H., \& Laney, "Toolkit: Board-ready slides on big data trends and opportunities.," Stamford, CT Gartner., 2013.

[21] R. Azuma, Y. Baillot, R. Behringer, S. Feiner, and B. Julier, S., \& MacIntyre, "Recent advances in augmented reality.," Comput. Graph. Appl., vol. 21, no. 6, pp. 34-47, 2001. https://doi.org/10.1109/38.963459

[22] P. S. Dunston, "Identification of application areas for augmented reality in Industrial construction based on technology suitability.," Autom. Constr., vol. 17, no. 7, pp. 882-894, 2008. https://doi.org/10.1016/j.autcon.2008.02.012

[23] S. Hah and J. Kim, D., \& Kim, "Mobile augmented reality interface (AR) design for user experience of library.," Korean Soc. Des. Sci., 2011.

[24] G. Camoprodon, S. Bigazzi, P. Pineda, and S. Tham, C., \& Mattia, "Samples of ongoing experiences in Europe.," Barcelona Coworking Eur. Conf., 2013.

[25] Y. Noh, "A study on creating and managing 'makerspaces' in libraries.," J. Korean Soc. Inf. Manag., vol. 31, no. 1, pp. 53-76, 2014.

[26] M. I. Qureshi et al., "Measuring the ecological footprint of inbound and outbound tourists: evidence from a panel of 35 countries," Clean Technol. Environ. Policy, 2019. https://doi. org/10.1007/s10098-019-01720-1

[27] M. I. Qureshi et al., "Modeling Work Practices under Socio-Technical Systems for Sustainable Manufacturing Performance," Sustainability, vol. 11, no. 16, p. 4294, Aug. 2019. https://doi.org/10.3390/su11164294

[28] M. I. Qureshi, R. M. Yusoff, S. S. Hishan, A. F. Alam, K. Zaman, and A. M. Rasli, "Natural disasters and Malaysian economic growth: policy reforms for disasters management," Environ. Sci. Pollut. Res., vol. 26, no. 15, pp. 15496-15509, May 2019. https://doi.org/10. 1007/s11356-019-04866-Z

[29] M. I. Qureshi, S. Qayyum, A. A. Nassani, A. M. Aldakhil, M. M. Q. Abro, and K. Zaman, "Management of various socio-economic factors under the United Nations sustainable development agenda," Resour. Policy, vol. 64, p. 101515, 2019. https://doi.org/10.1016/j.re $\underline{\text { sourpol.2019.101515 }}$ 
[30] Q. M. I. \& R. A. Harasis A. A., "Development of research continuous usage intention of ecommerce. A systematic review of literature from 2009 to 2015.," Int. J. Eng. Technol., vol. 7, no. 2.29 (2018), pp. 73-78, 2018. https://doi.org/10.14419/ijet.v7i2.29.13133

[31] M. Shahverdi, K. Ismail, and M. I. Qureshi, "The effect of perceived barriers on social entrepreneurship intention in Malaysian universities: The moderating role of education," Manag. Sci. Lett., vol. 8, no. 5, pp. 341-352, 2018. https://doi.org/10.5267/j.msl.2018.4.0 $\underline{14}$

[32] M. I. Qureshi, R. M. Yusoff, A. R. Ahmed, K. Isa, and A. Imran, "Linking quality of work life with sustainable manufacturing performance," Adv. Sci. Lett., vol. 23, no. 9, pp. 82328235, 2017. https://doi.org/10.1166/asl.2017.9867

[33] M. I. Qureshi, M. A. Hassan, S. S. Hishan, A. M. Rasli, and K. Zaman, "Dynamic linkages between sustainable tourism, energy, health and wealth: Evidence from top 80 international tourist destination cities in 37 countries,” J. Clean. Prod., vol. 158, pp. 143-155, 2017. https://doi.org/10.1016/j.jclepro.2017.05.001

[34] M. I. Qureshi, U. Awan, Z. Arshad, A. M. Rasli, K. Zaman, and F. Khan, "Dynamic linkages among energy consumption, air pollution, greenhouse gas emissions and agricultural production in Pakistan: sustainable agriculture key to policy success," Nat. Hazards, vol. 84, no. 1, pp. 367-381, 2016. https://doi.org/10.1007/s11069-016-2423-9

[35] M. I. Qureshi, A. M. Rasli, and K. Zaman, "Energy crisis, greenhouse gas emissions and sectoral growth reforms: Repairing the fabricated mosaic,” J. Clean. Prod., vol. 112, pp. 3657-3666, 2016. https://doi.org/10.1016/j.jclepro.2015.08.017

[36] M. I. Qureshi et al., "Environment and air pollution: health services bequeath to grotesque menace,” Environ. Sci. Pollut. Res., vol. 22, no. 5, pp. 3467-3476, 2015. https://doi.org/ 10.1007/s11356-014-3584-2

[37] M. I. Qureshi, N. U. Khan, A. M. Rasli, and K. Zaman, "The battle of health with environmental evils of Asian countries: promises to keep," Environ. Sci. Pollut. Res., vol. 22, no. 15, pp. 11708-11715, 2015. https://doi.org/10.1007/s11356-015-4440-8

[38] M. I. Qureshi, A. Md. Rasli, A. Jusoh, and T. O. Kowang, "Sustainability: A new manufacturing paradigm,” J. Teknol., vol. 77, no. 22, pp. 47-53, 2015. https://doi.org/10.11113/ jt.v77.6661

[39] M. I. Qureshi, M. Iftikhar, S. Y. Janjua, K. Zaman, U. M. Raja, and Y. Javed, "Empirical investigation of mobbing, stress and employees' behavior at work place: quantitatively refining a qualitative model," Qual. Quant., vol. 49, no. 1, pp. 93-113, 2015. https://doi.org/ $\underline{10.1007 / \mathrm{s} 11135-013-9976-4}$

[40] M. I. Qureshi, A. M. Rasli, and K. Zaman, "A New Trilogy to Understand the Relationship among Organizational Climate, Workplace Bullying and Employee Health," Arab Econ. Bus. J., vol. 9, no. 2, pp. 133-146, 2014. https://doi.org/10.1016/j.aebj.2014.05.009

[41] M. I. Qureshi, A. Khan, K. Zaman, and N. Khaqan, "Structural investigation of service quality in conventional and islamic banking in pakistan," Int. J. Manag. Innov., vol. 6, no. 1, p. 84, 2014.

[42] M. I. Qureshi, M. N. Bhatti, A. M. Rasli, M. Yasir, and K. Zaman, "The Delphi method for internationalization of higher education in Pakistan: Integrating theory of constraints and quality function deployment," Mediterr. J. Soc. Sci., vol. 5, no. 20, pp. 2702-2710, 2014. https://doi.org/10.5901/mjss.2014.v5n20p2702

[43] M. I. Qureshi, S. Y. Janjua, K. Zaman, M. S. Lodhi, and Y. Bin Tariq, "Internationalization of higher education institutions: Implementation of DMAIC cycle," Scientometrics, vol. 98, no. 3, pp. 2295-2310, 2014. https://doi.org/10.1007/s11192-013-1163-9 
[44] I. Q. Muhammad, B. Mansoor, K. Aamir, and Z. Khalid, "Measuring queuing system and time standards: A case study of student affairs in universities," African J. Bus. Manag., vol. 8, no. 2, pp. 80-88, 2014. https://doi.org/10.5897/ajbm2013.7247x

[45] A. M. Rasli, N. Norhalim, T. O. Kowang, and M. I. Qureshi, "Applying managerial competencies to overcome business constraints and create values evidence from small technology-based firms in Malaysia," J. Manag. Info, vol. 3, no. 1, pp. 99-121, 2014. https://doi. org/10.31580/jmi.v3i1.15

[46] M. Iftikhar and M. I. Qureshi, "Modeling the Workplace Bullying the Mediator of 'Workplace Climate-Employee Health' Relationship,” Journal Of Management Info, vol. 4, no. 1. pp. 96-124, 2014. https://doi.org/10.31580/jmi.v4i1.27

[47] R. B. M. Yusoff, A. Imran, M. I. Qureshi, and A. G. Kazi, "Investigating the relationship of employee empowerment and sustainable manufacturing performance," Int. Rev. Manag. Mark., vol. 6, no. 4, pp. 284-290, 2016.

[48] M. Iftikhar, M. U. Shahid, M. H. Shahab, M. Mobeen, and M. I. Qureshi, "Exploring the relationship among organizational citizenship behavior, psychological empowerment and turnover intensions with the mediating role of affective commitment," Int. Rev. Manag. Mark., vol. 6, no. 4, pp. 296-304, 2016.

\section{Authors}

Sabri Mohamad Sharif is affiliated with the Universiti Teknikal Malaysia Melaka (UTeM). Author is interested in the field of technology and innovation.For contact email at, Email: sabri@utem.edu.my

Ahmad Zam Hariro Samsudin works for Universiti Teknologi MARA (UiTM), Malaysia. Ahmad Zam is interested in the field of technology development in IR 4.0. For contact, Email: ahmadzam@gmail.com

Anum Shafeera Amdan works Universiti Teknologi MARA (UiTM), Malaysia. Author is interested in the field of technology and innovation. For contact email at Email: afisha86@yahoo.com

Article submitted 2020-01-30. Resubmitted 2020-03-19. Final acceptance 2020-03-23. Final version published as submitted by the authors. 